\title{
Impact of demographic factors on usage of stress coping strategies chosen by elderly people
}

\author{
DAGMARA LEMBAS ${ }^{1, \mathrm{~B}, \mathrm{D}-\mathrm{F}}$, ANNA STARKOWSKA ${ }^{1, \mathrm{c}, \mathrm{D}}$, MONIKA MAK ${ }^{1, \mathrm{E}, \mathrm{F}}$, MARIOLA KONECKA ${ }^{2, \mathrm{~B}, \mathrm{~F}}$ \\ MAGDALENA BIKOWSKA ${ }^{2, A, B, E, F}$, JOANNA CZARNOTA-CHLEWICKA ${ }^{2, \mathrm{~B}, \mathrm{~F}}$, \\ KATARZYNA GROSZEWSKA ${ }^{1, E}$, F, MARIA KORZONEK ${ }^{2, A, ~ B ~}$
}

\author{
${ }^{1}$ Independent Clinical Psychology Unit of the Department of Psychiatry and Psychiatric Clinic, Pomeranian Medical \\ University in Szczecin \\ ${ }^{2}$ Independent Long-term Care Unit, Pomeranian Medical University in Szczecin
}

A - Study Design, B - Data Collection, C - Statistical Analysis, D - Data Interpretation, E - Manuscript Preparation, F - Literature Search, G - Funds Collection

\begin{abstract}
Summary Background. Old age is a particular time in which people experience plenty of changes - both progressive and regressive. Their social and economic position is changing, and human beings are confronted with a lot of difficult situations, such as the death of a spouse, illness, retirement - which particularly require them to apply a proper strategy of coping with stress.

Objectives. The aim of this study was to analyze the relationship between the demographic factors and strategies of coping with stress used by elderly people.

Material and methods. The study was carried out on a group of 296 residents of Szczecin who are over 60 years old. It was conducted by means of a diagnostic survey with the use of the Inventory to Measure Coping Strategies with Stress - Mini-COPE, as well as an original questionnaire form. The statistical analysis was conducted by means of SPSS Statistics $21.0(p \leq 0.05)$.

Results. The results have proven the existence of a relationship between the strategies of coping with stress used by individuals over 60 and factors such as gender, level of education, economic status and financial situation.

Conclusions. When coping with stress, men and women apply different strategies. In case of individuals over 60, the higher level of education and financial status they declare, the more eager they are to use active strategies of coping with stress. Seniors with a lower level of education and lower economic status have more trouble adapting to difficult situations. They have problems with taking the initiative and actively dealing with stressful events. They also more often use psychoactive substances as part of their coping mechanism. Key words: strategies of coping with stress, elderly people, demographic factors, economic status.
\end{abstract}

Lembas D, Starkowska A, Mak M, Konecka M, Bikowska M, Czarnota-Chlewicka J, Groszewska K, Korzonek M. Impact of demographic factors on usage of stress coping strategies chosen by elderly people. Fam Med Prim Care Rev 2017; 19(1): 34-38, doi: 10.5114/fmpcr.2017.65088.

\section{Background}

Late adulthood is a particular period of human existence where multilevel and multidimensional changes occur - both progressive and regressive. It is not before retiring that individuals usually assess the outcome of their life and experience a lot of changes in their physical, psychological and social sphere [1]. An individual often feels as if they have no influence on the majority of changes in their life [2]. They face the necessity to come to terms with what they cannot change anymore and with aspects that are going to change for the worse. They experience the loss of what was important to them and what made their life worthwhile. The most common stressful situations for older individuals include deterioration of health, loss of physical strength and appearance, loss of family members and change of social and economic status, which lead to a feeling of loss of prestige and usefulness, as well as the awareness of impending death [3]. Similarly, Holmes and Rahe, in their SRRR scale (Social Readjustment Rating Scale), have identified 43 changes in life that are the most significant sources of stress for an individual. Among the first ten of the most stressful events for human beings are the death of a spouse, followed by divorce, separation, prison sentence, death of a close family member, illness or physical disability, marriage, unemployment, reconciliation with one's spouse and retirement $[4,5]$.

Difficult life situations require the use of appropriate strategies of coping with stress. "Coping" is understood as taking actions to reduce or eliminate both the causes of stress and its influence on physical and psychological health [6]. Individuals usually use more than one coping strategy, and their type is related to the overall level of stress [7]. Coping strategies that focus on a given problem and on emotions are considered healthy and effective strategies. The first one is chosen by individuals when they believe that through their actions, they are able to influence the stressful situation and are actively trying to eliminate the cause of stress. Strategies which focus on emotions are chosen when people believe they have no influence on stressinducing factors and are forced to accept the situation as it is. Usually, the higher amount of stressors a person experiences, the more often they use unique strategies of coping with stress [8] and the less they are willing to actively deal with them.

Study researchers have decided to verify whether sociodemographic factors and strategies of coping with stress used by individuals over 60 are in any way related.

\section{Objectives}

The aim of this paper was to analyze the relationship between the strategies of coping with stress used by individuals over 60 and factors such as gender, education, economic status and financial situation.

\section{Material and methods}

The study involved 296 citizens of Szczecin older than 60, both women (68.9\%) and men (31.1\%) 60-94 years of age 
( $M=71.61$ years of age; $S D=7.56$ ) (Table 1$)$. Selection of study group was random. Respondents represented the general population, and the research was conducted on an individual basis by employees of the Pomeranian Medical University in Szczecin. The locations for conducting the research included Social Nursing Homes, the Seniors' Medical University and Senior Club in Szczecin. The study was approved by the Bioethics Committee, approval no. KB-0012/144/13.

\begin{tabular}{|c|c|c|c|}
\hline & & $n$ & $\%$ \\
\hline \multirow[t]{3}{*}{ Age } & under 70 years & 147 & 49.7 \\
\hline & $70-79$ years & 99 & 33.4 \\
\hline & 80 and above & 50 & 16.9 \\
\hline \multirow[t]{2}{*}{ Gender } & women & 204 & 68.9 \\
\hline & men & 92 & 31.1 \\
\hline \multirow[t]{2}{*}{ Marital status } & single & 17 & 5.7 \\
\hline & married & 133 & 44.9 \\
\hline
\end{tabular}

The diagnostic interview method was used, including the following research tools:

- An original questionnaire form establishing the gender, level of education, economic status and financial situation of respondents.

- Charles S. Carver's Inventory to Measure Coping Strategies with Stress - Mini-COPE, adapted in Polish by Z. Juczyński and N. Ogińska-Bulik in 2009 [9]. The Polish version of the Mini-COPE inventory consists of 28 statements that are part of 14 strategies of coping with stress ( 2 statements per each strategy). Strategies such as Active Coping, Seeking Instrumental Support and Planning belong to problem-focused strategies. Coping methods such as Seeking Emotional Support, Turning to Religion or Denial are considered behaviors focused on emotions.

The Polish version of the Mini-COPE is based on a 7-factor scale. The first factor includes strategies of Active Coping such as Active Coping, Planning and Positive Reframing. Helplessness is reflected in strategies such as Using Psychoactive Substances, Ceasing Activity and Self-blame. Another factor - Seeking Support, includes both the Seeking Emotional Support strategy, related to emotions, and Seeking Instrumental Support, focused on the problem. Self-Distraction strategies, as well as Denial and Discharge, are related to Unique Behaviors. Individual factors make up such strategies as Turning to Religion, Acceptance and Sense of Humor [9].

The Mini-COPE inventory allows us to measure flexible coping - an evaluation of common ways of reacting and experiencing when exposed to an intense stress-inducing factor [9].

Statistical data was prepared by means of SPSS Statistics 21.0. The statistical significance of results was set at $p \leq 0.05$. Methods of independent groups comparison were used. Due to significant differences in numbers and the variance of the majority of results in standard normal distribution, nonparametric tests were selected: the Mann-Whitney $\mathrm{U}$ test for two groups, and the Kruskal-Wallis test for three or more groups. The average results for comparable groups and the overall significance are presented in tables. Details about the significance of differences between each group are described in the text.

\section{Results}

The obtained results indicate the presence of a relationship between strategies of coping with stress used by individuals over 60 and factors such as gender, education, economic status and financial situation. It was proven that in a stressful situation, women use coping strategies such as problem reframing, turning to religion and seeking emotional support, as well as self-distraction by means of different activities. Men cope with the negative effects of stress by using psychoactive substances, such as cigarettes, alcohol, etc. (Table 2).

\begin{tabular}{|l|l|l|l|l|}
\hline \multirow{2}{*}{ Table 2. Strategies of coping with stress in relation to gender } \\
\hline & $\begin{array}{l}\text { Women } \\
n=204\end{array}$ & $\begin{array}{l}\text { Men } \\
n=92\end{array}$ & \multicolumn{2}{l|}{$\begin{array}{l}\text { Mann-Whiteney } \\
\text { U test }\end{array}$} \\
\cline { 2 - 5 } & M/SD & M/SD & $\begin{array}{l}\text { Z test } \\
\text { value }\end{array}$ & $\begin{array}{l}\text { Signifi- } \\
\text { cance } p\end{array}$ \\
\hline Active coping & $4.22 / 1.52$ & $4.00 / 1.60$ & -1.057 & 0.291 \\
\hline Planning & $4.02 / 1.54$ & $3.77 / 1.63$ & -1.230 & 0.219 \\
\hline Positive reframing & $\mathbf{3 . 4 6 / 1 . 5 3}$ & $\mathbf{3 . 0 7 / 1 . 6 0}$ & $-\mathbf{2 . 0 1 4}$ & $\mathbf{0 . 0 4 4}$ \\
\hline Acceptance & $3.82 / 1.49$ & $3.63 / 1.57$ & -0.914 & 0.361 \\
\hline Humor & $1.58 / 1.60$ & $1.49 / 1.36$ & -0.012 & 0.990 \\
\hline Turning to religion & $\mathbf{3 . 3 5 / 2 . 2 1}$ & $\mathbf{2 . 4 1 / 2 . 1 4}$ & $-\mathbf{3 . 3 7 9}$ & $\mathbf{0 . 0 0 1}$ \\
\hline $\begin{array}{l}\text { Seeking emotional } \\
\text { support }\end{array}$ & $\mathbf{3 . 7 8 / 1 . 6 6}$ & $\mathbf{3 . 2 5 / 1 . 8 8}$ & $\mathbf{- 2 . 1 8 8}$ & $\mathbf{0 . 0 2 9}$ \\
\hline $\begin{array}{l}\text { Seeking instru- } \\
\text { mental support }\end{array}$ & $3.53 / 1.67$ & $3.25 / 1.69$ & -1.240 & 0.215 \\
\hline Self-distraction & $\mathbf{3 . 7 2 / 1 . 6 1}$ & $\mathbf{3 . 1 7 / 1 . 7 1}$ & $\mathbf{- 2 . 5 1 4}$ & $\mathbf{0 . 0 1 2}$ \\
\hline Denial & $2.07 / 1.77$ & $2.09 / 1.54$ & -0.447 & 0.655 \\
\hline Discharge & $2.93 / 1.55$ & $2.68 / 1.53$ & -1.605 & 0.108 \\
\hline $\begin{array}{l}\text { Using psychoac- } \\
\text { tive substances }\end{array}$ & $\mathbf{0 . 4 8 / 1 . 1 6}$ & $\mathbf{1 . 4 7 / 1 . 7 8}$ & $-\mathbf{5 . 8 1 1}$ & $\mathbf{0 . 0 0 1}$ \\
\hline Ceasing activity & $1.61 / 1.48$ & $1.61 / 1.50$ & -0.002 & 0.999 \\
\hline Self-blame & $2.41 / 1.68$ & $2.27 / 1.53$ & -0.589 & 0.556 \\
\hline
\end{tabular}

The results also indicate the importance of education in choosing specific coping strategies. It was observed that the higher the level of education, the higher the importance of planning the actions to be undertaken (Table 3). A decrease of tendencies to cease activity is also visible - in comparison to respondents with the lowest level of education, those with a high level of education achieved on average one point more on this scale $(p<0.001)$, and people with a medium level of education achieved approx. 0.7 points less $(p=0.013)$. Respondents with higher education deal with their problems in an active manner significantly more often than individuals with primary $(p=$ $0.002)$ and vocational education $(p=0.037)$. Moreover, they less often turn to religion, achieving an average of 0.9 raw points less on this scale $(p=0.011)$. Individuals with the lowest level of education are also less capable of accepting a stressful situation than those with a medium level of education $(p=0.005$ and 0.7 difference points). They also use positive reframing less often. In this strategy, they achieved approx. 0.8 points less than respondents with a medium $(p=0.002)$ and high $(p=0.005)$ level of education (Table 3).

In terms of financial situation, its improvement triggers a rise in willingness to seek social support (Table 4). The measurement of the need of emotional support revealed that in comparison to respondents with the worst financial situation, individuals with an average financial situation achieved approx. 0.8 points more, those with a good financial situation approx. 1 point more $(p=0.004)$, and those with a very good financial situation -1.3 points more $(p=0.003)$. Individuals with a very good financial situation needed more instrumental support than individuals with an average financial situation (achieving 0.7 raw points more; $p=0.031$ ) and a bad financial situation (achieving approx. 1.1 points more on average; $p=0.011$ ). Among respondents living in very good conditions, the tendency to cease activity is two times lower than among people living in good and average conditions $(p<0.001)$, and slightly more than 1.1 points lower than it is among respondents living in bad conditions $(p=$ 0.004) (Table 4).

The last analyzed factors were the living conditions of respondents (Table 5). It turns out that seniors who live in bad 
conditions more often use psychoactive substances - their average results on this scale were higher by almost 1.5 points than those in the group of individuals living in good conditions $(p=$ 0.020 ) and 1.6 points higher than those in the group of individuals living in very good conditions $(p=0.009)$. Seniors in the first group are the least capable of actively coping with stress. In the measurement of this strategy, they achieved 1.4 points less on average than individuals with good living conditions ( $p=0.008$ ) and 1.6 points less than individuals with very good living conditions $(p=0.004)$. There is also a significant difference in the tendency to plan actions to be undertaken under the influence of stress, and this is more defined among respondents living in very good conditions than among individuals who consider their living conditions bad (Table 5).

\begin{tabular}{|l|l|l|l|l|l|l|}
\hline Table 3. Strategies of coping with stress in relation to education \\
\hline \multirow{2}{*}{ Education } & $\begin{array}{l}\text { Primary } \\
n=52\end{array}$ & $\begin{array}{l}\text { Vocational } \\
n=77\end{array}$ & $\begin{array}{l}\text { Secondary } \\
n=92\end{array}$ & $\begin{array}{l}\text { Higher } \\
n=74\end{array}$ & \multicolumn{2}{l|}{ Kruskal-Wallis test } \\
\cline { 2 - 7 } & M/SD & M/SD & M/SD & M/SD & Test value & Significance $p$ \\
\hline Active coping & $\mathbf{3 . 7 7 / 1 . 5 0}$ & $\mathbf{4 . 0 9 / 1 . 5 3}$ & $\mathbf{4 . 1 1 / 1 . 5 9}$ & $\mathbf{4 . 5 5 / 1 . 5 0}$ & $\mathbf{1 0 . 3 6 7}$ & $\mathbf{0 . 0 1 6}$ \\
\hline Planning & $\mathbf{3 . 2 5 / 1 . 4 1}$ & $\mathbf{3 . 7 9 / 1 . 5 0}$ & $\mathbf{4 . 0 5 / 1 . 6 6}$ & $\mathbf{4 . 4 7 / 1 . 4 4}$ & $\mathbf{2 4 . 3 8 3}$ & $\mathbf{0 . 0 0 1}$ \\
\hline Positive reframing & $\mathbf{2 . 8 4 / 1 . 5 0}$ & $\mathbf{2 . 9 9 / 1 . 6 9}$ & $\mathbf{3 . 6 6 / 1 . 4 9}$ & $\mathbf{3 . 6 2 / 1 . 4 2}$ & $\mathbf{1 4 . 8 4 0}$ & $\mathbf{0 . 0 0 2}$ \\
\hline Acceptance & $\mathbf{3 . 2 9 / 1 . 5 9}$ & $\mathbf{3 . 7 8 / 1 . 5 1}$ & $\mathbf{4 . 0 0 / 1 . 5 4}$ & $\mathbf{3 . 7 8 / 1 . 4 0}$ & $\mathbf{8 . 2 1 8}$ & $\mathbf{0 . 0 4 2}$ \\
\hline Humor & $1.31 / 1.34$ & $1.46 / 1.47$ & $1.70 / 1.73$ & $1.61 / 1.46$ & 1.581 & 0.664 \\
\hline Turning to religion & $\mathbf{3 . 5 4 / 2 . 3 3}$ & $\mathbf{3 . 3 3 / 2 . 0 4}$ & $\mathbf{3 . 0 5 / 2 . 2 8}$ & $\mathbf{2 . 4 3 / 2 . 1 9}$ & $\mathbf{9 . 0 7 9}$ & $\mathbf{0 . 0 2 8}$ \\
\hline Seeking emotional support & $3.63 / 1.58$ & $3.64 / 1.93$ & $3.57 / 1.81$ & $3.64 / 1.81$ & 0.304 & 0.959 \\
\hline Seeking instrumental support & $3.42 / 1.59$ & $3.57 / 1.66$ & $3.29 / 1.79$ & $3.50 / 1.55$ & 0.680 & 0.878 \\
\hline Self-distraction & $3.31 / 1.69$ & $3.56 / 1.74$ & $3.61 / 1.66$ & $3.62 / 1.57$ & 1.611 & 0.657 \\
\hline Denial & $2.33 / 1.44$ & $2.26 / 1.52$ & $2.02 / 1.82$ & $1.78 / 1.87$ & 6.856 & 0.077 \\
\hline Discharge & $3.06 / 1.30$ & $2.91 / 1.73$ & $2.80 / 1.69$ & $2.72 / 1.30$ & 1.476 & 0.688 \\
\hline Using psychoactive substances & $0.98 / 1.74$ & $1.12 / 1.69$ & $0.62 / 1.22$ & $0.51 / 1.62$ & 6.696 & 0.082 \\
\hline Ceasing activity & $\mathbf{2 . 1 7 / 1 . 5 8}$ & $\mathbf{1 . 7 9 / 1 . 6 0}$ & $\mathbf{1 . 4 9 / 1 . 4 9}$ & $\mathbf{1 . 1 6 / 1 . 1 2}$ & $\mathbf{1 3 . 5 9 0}$ & $\mathbf{0 . 0 0 4}$ \\
\hline Self-blame & $2.58 / 1.58$ & $2.29 / 1.68$ & $2.18 / 1.78$ & $2.54 / 1.44$ & 4.057 & 0.255 \\
\hline
\end{tabular}

\begin{tabular}{|l|l|l|l|l|l|l|}
\hline \multicolumn{2}{|l}{ Table 4. Strategies of coping with stress in relation to financial situation } \\
\hline \multirow{2}{*}{ Financial situation } & $\begin{array}{l}\text { Bad } \\
n=32\end{array}$ & $\begin{array}{l}\text { Average } \\
n=109\end{array}$ & $\begin{array}{l}\text { Good } \\
n=115\end{array}$ & $\begin{array}{l}\text { Very good } \\
n=40\end{array}$ & \multicolumn{2}{l|}{ Kruskal-Wallis test } \\
\cline { 2 - 7 } & M/SD & M/SD & M/SD & M/SD & Test value & Significance $p$ \\
\hline Active coping & $4.03 / 1.84$ & $3.88 / 1.67$ & $4.26 / 1.37$ & $4.68 / 1.31$ & 7.913 & 0.095 \\
\hline Planning & $3.53 / 1.92$ & $3.77 / 1.61$ & $4.00 / 1.42$ & $4.55 / 1.43$ & 8.699 & 0.069 \\
\hline Positive reframing & $3.41 / 1.79$ & $3.30 / 1.55$ & $3.33 / 1.54$ & $3.38 / 1.52$ & 0.233 & 0.994 \\
\hline Acceptance & $4.00 / 1.59$ & $3.59 / 1.52$ & $3.89 / 1.47$ & $3.68 / 1.58$ & 3.150 & 0.533 \\
\hline Humor & $1.84 / 1.80$ & $1.63 / 1.57$ & $1.57 / 1.45$ & $1.05 / 1.34$ & 8.410 & 0.078 \\
\hline Turning to religion & $3.16 / 2.49$ & $2.98 / 2.16$ & $3.10 / 2.31$ & $3.10 / 1.98$ & 0.261 & 0.992 \\
\hline Seeking emotional support & $\mathbf{2 . 7 5 / 1 . 8 8}$ & $\mathbf{3 . 5 1 / 1 . 7 2}$ & $\mathbf{3 . 7 9} / 1.67$ & $\mathbf{4 . 0 8 / 1 . 6 7}$ & $\mathbf{1 6 . 2 4 8}$ & $\mathbf{0 . 0 0 3}$ \\
\hline Seeking instrumental support & $\mathbf{2 . 9 1 / 1 . 8 0}$ & $\mathbf{3 . 3 0 / 1 . 7 1}$ & $\mathbf{3 . 5 3 / 1 . 5 9}$ & $\mathbf{4 . 0 0 / 1 . 4 1}$ & $\mathbf{1 5 . 5 6 1}$ & $\mathbf{0 . 0 0 4}$ \\
\hline Self-distraction & $4.03 / 1.71$ & $3.34 / 1.68$ & $3.50 / 1.60$ & $3.88 / 1.65$ & 6.270 & 0.180 \\
\hline Denial & $2.16 / 1.83$ & $2.12 / 1.60$ & $2.04 / 1.67$ & $1.98 / 1.95$ & 2.730 & 0.604 \\
\hline Discharge & $3.13 / 1.54$ & $2.72 / 1.49$ & $3.00 / 1.59$ & $2.58 / 1.55$ & 7.894 & 0.096 \\
\hline Using psychoactive substances & $1.09 / 2.01$ & $0.84 / 1.40$ & $0.75 / 1.44$ & $0.48 / 1.06$ & 3.998 & 0.406 \\
\hline Ceasing activity & $\mathbf{1 . 9 7 / 1 . 7 7}$ & $\mathbf{1 . 6 8 / 1 . 3 6}$ & $\mathbf{1 . 7 0 / 1 . 5 0}$ & $\mathbf{0 . 8 5 / 1 . 3 1}$ & $\mathbf{1 8 . 4 9 7}$ & $\mathbf{0 . 0 0 1}$ \\
\hline Self-blame & $2.78 / 1.48$ & $2.39 / 1.57$ & $2.40 / 1.79$ & $1.90 / 1.41$ & 5.156 & 0.270 \\
\hline
\end{tabular}

\begin{tabular}{|l|l|l|l|l|l|l|}
\hline \multirow{2}{*}{ Table 5. Strategies of coping with stress in relation to living conditions } \\
& $\begin{array}{l}\text { Bad } \\
n=11\end{array}$ & $\begin{array}{l}\text { Average } \\
n=59\end{array}$ & $\begin{array}{l}\text { Good } \\
n=127\end{array}$ & $\begin{array}{l}\text { Very good } \\
n=99\end{array}$ & \multicolumn{2}{l|}{ Kruskal-Wallis test } \\
\cline { 2 - 7 } & M/SD & M/SD & M/SD & M/SD & Test value & Significance $p$ \\
\hline Active coping & $\mathbf{2 . 8 2 / 1 . 7 8}$ & $\mathbf{3 . 8 0 / 1 . 7 0}$ & $\mathbf{4 . 2 4 / 1 . 4 5}$ & $\mathbf{4 . 3 9 / 1 . 4 6}$ & $\mathbf{1 2 . 7 4 6}$ & $\mathbf{0 . 0 1 3}$ \\
\hline Planning & $\mathbf{2 . 9 1 / 1 . 5 8}$ & $\mathbf{3 . 6 8 / 1 . 6 4}$ & $\mathbf{3 . 8 7 / 1 . 4 5}$ & $\mathbf{4 . 3 1 / 1 . 5 9}$ & $\mathbf{1 4 . 9 9 2}$ & $\mathbf{0 . 0 0 5}$ \\
\hline Positive reframing & $2.91 / 1.45$ & $3.12 / 1.61$ & $3.33 / 1.56$ & $3.52 / 1.55$ & 3.935 & 0.415 \\
\hline Acceptance & $3.73 / 1.62$ & $3.44 / 1.73$ & $3.73 / 1.37$ & $3.99 / 1.53$ & 7.401 & 0.116 \\
\hline Humor & $1.18 / 1.33$ & $1.42 / 1.64$ & $1.72 / 1.53$ & $1.45 / 1.47$ & 4.406 & 0.354 \\
\hline Turning to religion & $1.73 / 2.20$ & $3.03 / 2.27$ & $3.23 / 2.18$ & $3.00 / 2.25$ & 5.052 & 0.282 \\
\hline Seeking emotional support & $\mathbf{1 . 8 2 / 1 . 1 7}$ & $\mathbf{3 . 4 7 / 1 . 7 7}$ & $\mathbf{3 . 7 6 / 1 . 6 2}$ & $\mathbf{3 . 7 1 / 1 . 8 4}$ & $\mathbf{1 4 . 0 9 7}$ & $\mathbf{0 . 0 0 7}$ \\
\hline
\end{tabular}




\begin{tabular}{|l|l|l|l|l|l|l|}
\hline Table 5. Strategies of coping with stress in relation to living conditions \\
\hline \multirow{2}{*}{ Living conditions } & $\begin{array}{l}\text { Bad } \\
n=11\end{array}$ & $\begin{array}{l}\text { Average } \\
n=59\end{array}$ & $\begin{array}{l}\text { Good } \\
n=127\end{array}$ & $\begin{array}{l}\text { Very good } \\
n=99\end{array}$ & \multicolumn{2}{l|}{ Kruskal-Wallis test } \\
\cline { 2 - 7 } & M/SD & M/SD & M/SD & M/SD & Test value & Significance $p$ \\
\hline Seeking instrumental support & $2.82 / 1.66$ & $3.22 / 1.88$ & $3.64 / 1.40$ & $3.39 / 1.80$ & 3.537 & 0.472 \\
\hline Self-distraction & $\mathbf{3 . 7 3 / 1 . 9 0}$ & $\mathbf{3 . 3 6 / 1 . 6 9}$ & $\mathbf{3 . 4 6 / 1 . 6 4}$ & $\mathbf{3 . 7 7 / 1 . 6 4}$ & $\mathbf{1 0 . 8 8 3}$ & $\mathbf{0 . 0 2 8}$ \\
\hline Denial & $1.91 / 1.64$ & $2.39 / 1.62$ & $1.93 / 1.63$ & $2.09 / 1.82$ & 4.396 & 0.355 \\
\hline Discharge & $2.45 / 1.51$ & $2.75 / 1.52$ & $2.87 / 1.58$ & $2.95 / 1.54$ & 4.911 & 0.297 \\
\hline Using psychoactive substances & $\mathbf{2 . 1 8 / 2 . 4 8}$ & $\mathbf{1 . 0 5 / 1 . 5 7}$ & $\mathbf{0 . 7 2 / 1 . 3 9}$ & $\mathbf{0 . 5 6 / 1 . 2 2}$ & $\mathbf{1 0 . 6 9 4}$ & $\mathbf{0 . 0 3 0}$ \\
\hline Ceasing activity & $2.09 / 1.92$ & $1.78 / 1.59$ & $1.70 / 1.44$ & $1.33 / 1.40$ & 5.576 & 0.233 \\
\hline Self-blame & $2.36 / 1.03$ & $2.41 / 1.75$ & $2.46 / 1.68$ & $2.23 / 1.57$ & 1.214 & 0.876 \\
\hline
\end{tabular}

\section{Discussion}

Old age, also known as the "age of loss", is associated with numerous negative changes in the environment of seniors [10]. The reaction to stress and selection of particular coping strategies are highly dependent on specific demographic factors. Study results have shown that women and men vary in terms of the coping strategies they use (Table 2). In stressful situations, women use strategies focused on emotions. This matter is also discussed by Scott and Melin [11]. According to the authors, in the course of their lives, women face more difficulties related to the necessity of fulfilling many roles simultaneously [11]. At the same time, due to having a certain ease in establishing human relations, women create strategies of seeking social support, which belong to strategies focused on emotions. On the other hand, men use psychoactive substances to elevate the effects of stress.

In terms of education - as the individual study has shown - seniors with the lowest level of education least often use positive reframing, and they experience difficulties in accepting stressful situations (Table 3). The higher the level of education they have, the more active they are in trying to eliminate the cause of stress by means of strategies focused on the problem. Similarly, Sygit-Kowalkowska et al. have proven the existence of the statistically significant relationship between the level of education and the results achieved on the "active coping" scale. A higher level of education means a better active coping capability, whereas a lower level of education causes this skill to worsen [12].

The economic situation of respondents has also proven to be significant in choosing coping strategies (Table 4). The better it is, the greater the tendency of respondents to seek social support - both emotional and instrumental. Living conditions are also important (Table 5). People living in bad conditions less often deal with problems in an active way and significantly more often use psychoactive substances. On the other hand, seniors living in very good conditions show a two times weaker tendency to cease activity.

Therefore, primary care physicians need to take into account a variety of demographic factors of the elderly when dealing with $60+$ patients with difficult life experiences such as retirement, death of their spouse or illness. Special attention ought to be paid to those $60+$ patients whose level of education and overall living conditions are worse. As the study has shown, they are the group of people less capable of adapting to such situations, having difficulties in active coping and taking the initiative and actions to limit the effects of a stressful event. This group also has the highest percentage of patients addicted to psychoactive substances. A course of action worth considering is helping seniors by encouraging them to actively participate in local community centers for $60+$ citizens or the socalled Universities of the Third Age, which are becoming more and more popular. As various studies show, the social and intellectual activity of seniors who are students results in more joy of life for them, a better mood and a subjective good assessment of health by the elderly [13]. An effective social support network for people diagnosed with cancer, arthritis, heart conditions or diabetes results in shorter recovery periods for such patients [14]. Meeting other individuals and actively spending time with them has a positive effect on a human's lifespan [13], similarly to joy and positive emotions, which are some of the most important predictors of a long and healthy life [6].

\section{Conclusions}

After conducting the study, the following conclusions were drawn:

1. When providing care for $60+$ patients experiencing severely stressful life situations, demographic factors such as gender, education, financial situation and living conditions need to be taken into consideration. Seniors with a low economic status and with a low level of education, in problematic situations, have problems with handling stress actively and also with taking the initiative. They also more often reach for psychoactive substances. Active stress coping strategies are preferred by individuals over 60 with a higher level of education and with a higher financial status.

2. For primary care physicians, particularly important cases are going to be those revolving around $60+$ patients who show helplessness and display avoidance behaviors under the influence of stressful factors.

3. Taking into account the aforementioned demographic factors in 60+ patients in difficult life situations will make it possible to establish their preferred coping strategy and offer them the type of support appropriate for their coping capabilities.

\section{References}

1. Mastalerz-Migas A, Ościłowska E, Steciwko A. Jakość życia osób w wieku podeszłym. Fam Med Prim Care Rev 2008; 10(3): 511-514.

2. Izdebski P, Jurga M, Kosiol M. Bilans życiowy a postawa wobec śmierci w późnej dorosłości. Gerontol Pol 2012; 20(4): 155-159.

3. Straś-Romanowska M. Późna dorosłość. Wiek starzenia się. In: Harwas-Napierała B, Trempała J, eds. Psychologia rozwoju człowieka. Charakterystyka okresów życia człowieka. Vol. 2. Warszawa: PWN; 2007: 263-292. 
4. Holmes TH, Rahe RH. The social readjustment rating scale. J Psychosom Res 1967; 11(2): 213-218.

5. Strelau J, red. Psychologia. Podręcznik akademicki. Vol. 3. Gdańsk: Gdańskie Wydawnictwo Psychologiczne; 2007: 493-512.

6. Zimbardo PG, Johnson RL, McCann V. Psychologia. Kluczowe koncepcje. Warszawa: PWN; 2010.

7. Kosslyn SM, Rosenberg RS. Psychologia. Mózg. Człowiek. Świat. Kraków: Znak; 2006: 603-620.

8. Ingledew DK, Hardy L, Cooper CL. Do resources bolster coping and does coping buffer stress? An organizational study with longitudinal aspect and control for negative affectivity. Journal of Occupational Health Psychology 1997; 2: 352-359.

9. Juczyński Z. Inwentarz do Pomiaru Radzenia Sobie ze Stresem MINI-COPE. In: Narzędzia pomiaru stresu i radzenia sobie ze stresem. Warszawa: Pracownia Testów Psychologicznych 2009; 45-58.

10. Zielińska-Więczkowska H, Kędziora-Kornatowska K, Kornatowski T. Starość jako wyzwanie. Gerontol Pol 2008; 16(3): 131-136.

11. Scott B, Melin L. Psychometric properties and standardized data for questionnaries measuring negative affect, dispositional style and daily hassles: a nation-wide sample. Scand J Psychol 1998; 39: 301-307.

12. Sygit-Kowalkowska E. Inteligencja emocjonalna a strategie radzenia sobie ze stresem. Psychologiczna analiza funkcjonowania mieszkańców ośrodków pomocy społecznej i studentów uniwersytetu trzeciego wieku. Gerontol Pol 2013; 21(3): 98-108.

13. Żurek G, Żurek A, Pirogowicz I, et al. Wybrane aspekty jakości życia i ogólnego stanu zdrowia w badaniach słuchaczek Uniwersytetu Trzeciego Wieku w Opolu. Fam Med Prim Care Rev 2011; 13(3): 556-562.

14. Taylor SE. Health Psychology. New York: McGraw-Hill; 2006.

Tables: 5

Figures: 0

References: 14

Received: 28.07.2016

Revised: 07.11.2016

Accepted: 07.11.2016

Address for correspondence:

Maria Korzonek, MD

Samodzielna Pracownia Opieki Długoterminowej PUM

ul. gen. Dezyderego Chłapowskiego 11

70-103 Szczecin

Polska

Tel.: +48 91 44-14-758

E-mail: korzspod@pum.edu.pl 